\title{
Stock Market Development and Economic Growth: Evidences from Egypt
}

\author{
Osama M. Badr
}

\begin{abstract}
This study investigates the causal relationship between stock market development and economic growth in Egypt. To achieve this objective, unit root tests were conducted for time series data for the period of 2002 to 2013 in their levels and their first differences according to Dickey-Fuller. Johansen co-integration analysis was conducted to examine whether the variables are co-integrated of the same order. Vector autoregression estimates (VAR) was chosen to test the long-run relationship between stock market development and economic growth. VAR Granger Causality test was applied to determine the direction of causality between the examined variables. Finally, Variance Decomposition and Impulse response function (IRF) were used for forecasting the future relationship between the study variables. The results do not indicate a causal relationship between stock market development alone and the economic growth. However, the results show a link between stock market development as well as foreign direct investment and economic growth. Therefore, it can be inferred that government should reshape and adjust the stock market and take care of FDI to support economic growth.
\end{abstract}

Index Terms-Stock market development, economic growth, vector autoregression estimates (VAR), VAR Granger Causality, variance decomposition, impulse response function, Egypt.

\section{INTRODUCTION}

A long debate about the role of Stock Market development on economic growth process is far from being a new issue. It has started since early research of Schumpeter (1911) and McKinnon (1973). It increased the importance of financial markets across the world and renewed the interest to know whether development of stock market can promote long-run economic growth. This helps governments, especially in developing countries, follow the appropriate economic policy or/and reshape the financial sector that supports its economic growth. Few years later, some studies examined the development role of stock markets as a pillar in national economy and its effect on economic growth. These studies have emphasized that the capital market plays a pivotal role, which affects the national economic growth. However, all economies are not following this emphasis. For that, it would be interesting to examine whether this relationship is a feature of the developing countries. In this paper, we conduct an empirical analysis on the causal relationship between the stock market and economic growth in one of the developing economies,

Manuscript received January 6, 2015; revised April 27, 2015.

Osama M. Badr is with the Faculty of Commerce, Tanta University, Egypt. He is also with the College of Business, Umm Al-Qura University, KSA (e-mail: ombadr@uqu.edu.sa).
Egypt during the critical economic period of 2002 to 2013. Thus, this paper attempts to answer the following questions: Does the Egyptian stock market enhance economic growth? Is the effect of stock market on economic growth pronounced? Therefore this study tests the following hypothesis: Stock market development causes economic growth. To achieve this, Vector Autoregression Estimates (VAR), VAR Granger Causality and Impulse Response Function are employed.

\section{LITERATURE REVIEW}

A large body of literature has been developed trying to examine whether there is a financial market role to support economic growth and vice versa. Due to the importance of the question, researchers and economists have paid attention to determine which of both alternatives is the most relevant, especially that the empirical literature has progressively evolved to using time series new techniques, as it helps them offer different views about the stock market role in boosting economic growth and have varied in methods and results. While early studies support that the causality goes from stock market to economic growth, the most recent studies do not give a clear idea about causality direction. These studies can be divided into three groups. The first group of studies has found a significant relationship between stock market development and economic growth e.g. Filer, Hanousek \& Campos investigates the relationship between stock markets and economic growth in 70 countries through the period 1985 to 1997 by using Granger causality tests. They found a little relationship between stock market activity and future economic growth, especially for the lower income countries in investigated sample [1]. Beck \& Levine investigate the impact of stock markets and banks on economic growth in 40 countries through the period 1976 to 1998 by using generalized-method-of moments (GMM). They found positively influence between stock markets and economic growth [2]. Choong, Yusop, Law \& Liew aim to understanding the long- and short-run causal relationship between financial development and economic growth in Malaysia by using ARDL test, VECM test and Granger causality tests. They found positive long- and short-run impact of stock market development on economic growth [3]. Bahadur examines the existence of causal relationship between stock market and economic growth in Nepal through the period 1988 to 2005 by using Granger causality test. He found causal relation in real terms but not in nominal variables which indicate that the stock market plays significant role in determining economic growth and vice versa [4]. Ang \& McKibbin examine if financial development leads to economic growth in Malaysia through 
the period 1960 to 2001 by using cointegration and VAR causality tests. They found that financial development causes economic growth in the long run [5]. Liu \& Sinclair investigate the relationship between stock market performance and economic growth in Greater China through the period 1973 to 2003 by using causality tests within the VECM framework. They found one-way causality running from economic growth to stock prices in the long run and also running from stock prices to economic growth in the short run [6]. Vazakidis \& Adamopoulos investigate the causal relationship between financial development and economic growth in Greece the period 1978 to 2007 by using VECM and Granger causality tests. They found that economic growth has a positive effect on stock market development [7]. Karacaer Kapusuzoglu examines the longand short-term dynamics relationships between the stock price index and basic macroeconomic factors; such as (inflation, industrial output and exchange rate) as proxy of economic growth in Turkey through the period 2003 to 2010 by using Johansen Cointegration and Granger causality tests. He found a long-term cointegration relationship between variables, while in the short-run, there were unidirectional and bidirectional causal relations among the variables [8]. Marques, Fuinhas \& Marques investigate the relationship between stock market and economic growth in Portugal through the period1993 to 2011 by using VAR model, Granger causality test and impulse responses function. They found evidence of positive causal relationship between stock market development and economic growth [9]. Cavenaile, Gengenbach \& Palm investigate the long run relationship between the development of banks and stock markets and economic growth and causality direction in five countries through the period 1977 to 2007 by using Unit Root Test, Cointegration Test and Causality Test. They found single cointegrating vector between financial development and growth. There was also a causality going from financial development to economic growth [10]. Rad \& Etemadmoghaddamb examine the long- and short-run effects of stock market development and banking sector development on economic growth in Iran through the period 1995 to 2010 by using (ARDL) to test long-run relationship \& (ECM) to test shortrun relationship. They found that the stock market development is an important ingredient of growth in the long-run [11].

On the other hand, stock market development has a significant effect on economic growth on short-run. The second group of studies did not find a significant relationship between stock market development and economic growth e.g. Zhao examines the relationship between stock returns and economic growth in China through the period 1993 to 1998 by using OLS regression on monthly data. He found that expected economic growth has a significant negative effect on stock returns. However, he did not test the reverse effect from stock returns to economic growth [12]. Naceur \& Ghazouani, identify the relationship between banks and stock markets development and economic growth in 11 MENA region countries through the period 1979 to 2003 by using generalized-method-of moments (GMM). They found that the empirical results adopt the idea of no significant relationship between stock market development and economic growth even after controlling and adjusting the stock market development [13]. Azarmi, Lazar \& Jeyapaul evaluate the relation between stock market development and economic growth in India through the period 1981 to 2001 by using time-series regression. They found positive relation for the preliberalization period and negative for the post-liberalization period, which consider Indian stock market as a casino that is not contributing to the economic growth of the country [14]. Carp analyzes the dynamic of the stock market and the impact of the volatility of the foreign capital inflows as proxy of economic growth in Central and Eastern Europe through the period 2000 to 2007 by using Granger causality tests. They found that market capitalization and stock value traded do not exert any impact on economic growth rates [15].

The Third group of studies did not find a relationship between stock market development and economic growth in a period; however, they find a relationship between stock market development and economic growth in another period e.g. Rioja \& Valev investigate the effects of stock markets on economic growth in low and high income countries by using dynamic panel Generalized-method-of-moments (GMM). They found that stock markets have not contributed to capital accumulation or productivity growth in lowincome countries. Conversely, stock markets have sizable positive effects on both productivity and capital growth in high-income countries [16]. Guo examines the causal relation between stock returns and real economic growth in China by using nonuniform weighting cross-correlation approach and the multivariate generalized autoregressive conditional heteroscedasticity model. He found that there is no a causal relationship between China's stock returns and the real economic growth in the period before the subprime crisis. However, there is unidirectional causal relation in mean from real economic growth to stock returns and unidirectional causal relation in variance from stock returns to real economic growth for the period after the subprime crisis [17].

From the above discussion, although the economic thought supports a significant and positive relationship between stock market development and economic growth as the stock market plays a significant role in financing the necessary projects of economic development instead of government funds, the results of previous studies vary from market to another and conclude that there may be a causal relationship between financial development and economic growth in one country and does not exist in another country.

\section{MEthodology}

Testing causality among variables is one of the vital issues in economics. VAR can be considered as a means of conducting Granger causality tests. As per Granger (1988)" causality really implies a correlation between the current value of one variable and the past values of others; it does not mean changes in one variable cause changes in another, causality must exist in at least one direction which indicates the presence of Granger causality". Thus, According to Granger, "It is possible to have causality running from variable $X$ to $Y$, but not $Y$ to $X$; from $Y$ to $X$, but not $X$ to $Y$ 
and from both $Y$ to $X$ and $X$ to $Y$, although in this case interpretation of the relationship is difficult". It means that if the past value of $X$ statistically improve the prediction of $Y$, it can be concluded that $X$ Granger- cause $Y$. Then by using F-test to jointly test for the significance of the lags on the explanatory variables; this in effect tests for 'Granger causality' between these variables.

This study uses the VAR Granger causality test for examining the causality between stock market development and economic growth using time-series data-based approach as it provides a powerful test to investigate the causality in varied types of situation and to test whether stock market "Granger- cause" economic growth and vice versa. The following model is tested.

$$
X_{t}=A_{0}+\sum_{i=1}^{p} A_{i} X_{t-i}+e_{t} \ldots
$$

where

$A_{0}$ is a $4 \times 1$ vector of constant terms,

$A_{i}$ is a $4 \times 4$ matrix of coefficients,

$e_{t}$ is a $4 \times 1$ vector of error terms,

$p$ is the optimal lag order set to render the error terms serially uncorrelated.

Cholesky orthogonalization strategy was adopted to generate impulse-response functions and variance decompositions, which states that the recursive simulation structure requires pre-specified causal ordering of the variables, where a variable that is ordered first in the ordering is viewed to respond to other variables with lags while a variable that is ordered second responds contemporaneously to the first-ordered variable and with lags to the remaining variables.

This means that the variable ordered last is most endogenous since it reacts contemporaneously to other variables in the equation. Based on this, our variables' ordering is gross domestic production (GDP), foreign direct investment (FDI) and stock market capitalization (CAP), which is believed to be sensible. Meanwhile, the following step is running the Variance Decomposition (VD) and Impulse Response Function (IRF) analyses.

Thus, the following error correction model for stock market development is estimated as follows:

$$
\Delta C a p_{t}=a+\sum_{\substack{i=1 \\ \sum_{i=1}^{p 3} \emptyset_{i} \Delta C a p_{t-1}+e_{t}}}^{p 1} \beta_{i} \Delta R G D P_{t-1}+\sum_{i=1}^{p 2} \emptyset_{i} \Delta F D I_{t-1}+
$$

where

$\Delta$ is the first-difference level,

CAP is the stock market capitalization,

RGDP is the real gross domestic production,

FDI is the foreign direct investment.

\section{DATA}

To test the causality between stock market development and economic growth, Real GDP and FDI are used as proxies for the economic growth. Despite the criticism of the GDP, it remains a useful measure of human well-being; thus, the growth is usually calculated in real terms that prevent the distorting effect of inflation. Also, FDI is regarded as a good proxy for economy growth because FDI eases the access to international markets and the transfer of technology which boosts the growth. In the same time, market capitalization of all listed companies in the Egyptian stock market is employed as a proxy for the stock market development. While stock market is traded in the capital market, and capitalization is regarded as a useful measure of public opinions of a company's net worth, the total capitalization of the stock markets as a whole provides a precise snapshot of the stock market and can be compared with such economic indicators as GDP and FDI. In this paper, the quarterly data used rather than annual data to have good and effective observation changes in RGDP, FDI and market capitalization over time. All data analyzed in this paper are taken from The Egyptian Ministry of Planning, Egypt Information Portal, Egyptian Stock Exchange and World development indicators, for the period from the first quarter of 2002 to fourth quarter of 2013.

\section{EMPIRICAL RESULTS}

The first step in empirical analysis is to test the unit root for stationarity. Table I shows the result of testing the stationarity of the economic growth and stock market variables from the first quarter of 2002 to the fourth quarter of 2013 using the Augmented Dicky Fuller unit root test (ADF) and the Phillips Perron unit root test (PP) at their level and their first difference level. The null hypothesis of non-stationarity is performed at the $5 \%$ significance level, which reflects that the economic growth and stock market series are non-stationary at their level; however, they are stationary in their first difference at the $5 \%$ significance level. Since the series are stationary in their first difference, the Akaike information Criterion (AIC) is employed to find the optimal length of lags for the vector autoregression model (VAR).

\begin{tabular}{lllll}
\multicolumn{4}{l}{ TABLE I: ADF AND PP UNIT ROOT TESTS } \\
\hline Level & ADF & RGDP & FDI & CAP \\
& Prob.* & -0.735000 & -1.525430 & -2.508199 \\
& PP & -9637 & 0.8065 & 0.3230 \\
& Prob.* & 0.0550 & -1.539363 & -2.424825 \\
\hline First & ADF & -3.593027 & -6.825795 & -5.756919 \\
Difference & Prob.* & 0.0423 & 0.0000 & 0.0001 \\
& PP & -11.42124 & -6.825826 & -11.37936 \\
& Prob.* & 0.0000 & 0.0000 & 0.0000 \\
\hline
\end{tabular}

Note: The test equations include both drift and trend terms. The lag order in the ADF test equation is based on AIC. * and ** denote significance at $1 \%$ and $5 \%$ respectively.

The second step in our analysis is to examine the cointegration between the variables to test if economic variables share the same trend so that they are combined together in the long run. Even if they differ from each other in the short run; they tend to come back to the trend in the long run. Taking into consideration the necessary conditions of Engle and Granger, 1991 for the cointegration test is that "all the variables should be integrated at the same order or contain a deterministic trend". In Table II, as the Prob. Values are more than $5 \%$ and the statistic value is smaller than critical values in both Trace and Maximum Eigenvalue tests', we cannot reject the null hypothesis, which means that 
the variables are not cointegrated in the long run.

TABLE II: UNRESTRICTED COINTEGRATION RANK TEST

\begin{tabular}{|c|c|c|c|c|}
\hline & $\begin{array}{l}\text { Hypothesized } \\
\text { No. of } \mathrm{CE}(\mathrm{s})\end{array}$ & None & At most 1 & At most 2 \\
\hline Trace & $\begin{array}{c}\text { Eigenvalue } \\
\text { Statistic } \\
\text { Critical } \\
\text { Prob.** } \\
\end{array}$ & $\begin{array}{c}0.274399 \\
22.13568 \\
29.79707 \\
0.2910 \\
\end{array}$ & $\begin{array}{c}0.137142 \\
8.343224 \\
15.49471 \\
0.4294 \\
\end{array}$ & $\begin{array}{c}0.045458 \\
2.000495 \\
3.841466 \\
0.1572\end{array}$ \\
\hline $\begin{array}{l}\text { Maximum } \\
\text { Eigenvalue }\end{array}$ & $\begin{array}{c}\text { Eigenvalue } \\
\text { Statistic } \\
\text { Critical } \\
\text { Prob.** }\end{array}$ & $\begin{array}{c}0.274399 \\
13.79246 \\
21.13162 \\
0.3823\end{array}$ & $\begin{array}{c}0.137142 \\
6.342730 \\
14.26460 \\
0.5696\end{array}$ & $\begin{array}{c}0.045458 \\
2.000495 \\
3.841466 \\
0.1572\end{array}$ \\
\hline
\end{tabular}

Note: The lag order in the test system is set to 4 , which is sufficient to render the error terms uncorrelated

However, although there is no a cointegration between the variables in the long run, we can still check the presence of Granger causality between the variables, as we cannot run the vector error-correction model (VECM) because there is no cointegration between the variables but we estimate the first level difference VAR to discern dynamic causal interactions among the variables in the system instead. The VAR lag order is set automatically as per Akaike (AIC) criterion. It is worth emphasizing that the Granger causality test is very sensitive to the number of lags included in the regression and the AIC is the most common criterion employed in previous literature.

Table III presents for the VAR estimations. The table shows that RGDP is statistically affected by the first and fourth lag periods of RGDP and the first lag period of CAP FDI is statistically affected by the first lag period of FDI. CAP is statistically affected by the second lag period of FDI and the first lag period of CAP has been detected.

TABLE III: VECTOR AUTOREGRESSION ESTIMATES

\begin{tabular}{|c|c|c|c|}
\hline & RGDP & FDI & CAP \\
\hline \multirow[t]{2}{*}{ RGDP(-1) } & $0.447074 *$ & -0.420729 & 40.86890 \\
\hline & $(0.0021)$ & $(0.9800)$ & $(0.3005)$ \\
\hline \multirow[t]{2}{*}{ RGDP(-2) } & -0.141708 & 3.215164 & -68.94830 \\
\hline & $(0.3755)$ & $(0.8651)$ & $(0.1219)$ \\
\hline \multirow[t]{2}{*}{ RGDP(-3) } & 0.044347 & -2.520887 & 57.26370 \\
\hline & $(0.7831)$ & $(0.8950)$ & $(0.2022)$ \\
\hline \multirow{2}{*}{ RGDP(-4) } & $0.614533 *$ & -0.013564 & -9.768754 \\
\hline & $(0.0000)$ & $(0.9993)$ & $(0.7985)$ \\
\hline \multirow[t]{2}{*}{$\overline{\mathrm{FDI}(-1)}$} & 0.001154 & $0.918629^{*}$ & -0.247651 \\
\hline & $(0.4589)$ & $(0.0000)$ & $(0.5666)$ \\
\hline \multirow[t]{2}{*}{ FDI(-2) } & -0.000659 & -0.018223 & $1.296647^{*}$ \\
\hline & $(0.75350)$ & $(0.9416)$ & $(0.0280)$ \\
\hline \multirow[t]{2}{*}{ FDI(-3) } & 0.001456 & 0.135442 & -0.115104 \\
\hline & $(0.5090)$ & $(0.6043)$ & $(0.8506)$ \\
\hline \multirow[t]{2}{*}{ FDI(-4) } & 0.002561 & -0.030261 & 0.385752 \\
\hline & $(0.1555)$ & $(0.8869)$ & $(0.4391)$ \\
\hline \multirow[t]{2}{*}{$\overline{\mathrm{CAP}}(-1)$} & $-0.001458 *$ & -0.070132 & $0.550150^{*}$ \\
\hline & $(0.0320)$ & $(0.3797)$ & $(0.0039)$ \\
\hline \multirow[t]{2}{*}{ CAP(-2) } & $6.27 \mathrm{E}-05$ & 0.085333 & -0.326941 \\
\hline & $(0.9369)$ & $(0.3647)$ & $(0.1393)$ \\
\hline \multirow[t]{2}{*}{ CAP(-3) } & 0.000213 & -0.080375 & -0.187882 \\
\hline & $(0.7818)$ & $(0.3803)$ & $(0.3808)$ \\
\hline \multirow[t]{2}{*}{ CAP(-4) } & -0.001002 & -0.024751 & -0.010733 \\
\hline & $(0.1319)$ & $(0.7523)$ & $(0.9533)$ \\
\hline \multirow[t]{2}{*}{$\overline{\mathrm{C}}$} & 50.06391 & 1416.615 & -9225.091 \\
\hline & $(0.0918)$ & $(0.6854)$ & $(0.2610)$ \\
\hline
\end{tabular}

Note: Sample (adjusted): 2003Q1 2013Q4 Included observations: 44 after adjustments and Prob. in ( ). * significant at $5 \%$

Table IV is divided into three parts, which show the relationship between RGDP, FDI and CAP In the first part, a significant causal relationship at $5 \%$ between FDI and RGDP was found. Meanwhile, we do not find a causal relationship between CAP and RGDP, which is not consistent with the economic theory but is jointly together as there is a significant causal relationship at $10 \%$ between FDI \& Cap and RGDP. In the second part, there is no a significant causal relationship between FDI and RGDP or CAP In the third part, there is a significant causal relationship between FDI and Cap at $1 \%$. It can be noted that there is no a causal relationship between CAP and RGDP or Cap and FDI. This means that there is no causal relationship between stock market development alone and the economic growth. These results are consistent with the studies of Zhao (1999), Naceur \& Ghazouani (2007), Azarmi, Lazar \& Jeyapaul (2011) and Carp (2012) who find that the stock market development is not associated with the economic growth.

TABLE IV: VAR GRANGER CAUSALITY/BLOCK EXOGENEITY WALD TESTS

\begin{tabular}{lllrl}
\hline & Excluded & Chi-sq & df & Prob. \\
\hline RGDP as & FDI & $10.083^{* *}$ & 4 & 0.0390 \\
Dependent & CAP & 6.661 & 4 & 0.1549 \\
variable & Jointly & $13.363 * * *$ & 8 & 0.0999 \\
\hline FDI as & RGDP & 0.042 & 4 & 0.9998 \\
Dependent & CAP & 1.849 & 4 & 0.7634 \\
variable & Jointly & 2.938 & 8 & 0.9382 \\
\hline CAP as & RGDP & 5.77 & 4 & 0.2170 \\
Dependent & FDI & $18.165^{*}$ & 4 & 0.0011 \\
variable & Jointly & $21.807^{*}$ & 8 & 0.0053 \\
\hline
\end{tabular}

Note: Sample: 2002Q1 2013Q4 Included observations: 44. * significant at $1 \% * *$ significant at $5 \% * * *$ significant at $10 \%$

TABLE V: VARIANCE DECOMPOSITION

\begin{tabular}{cccccc}
\hline $\begin{array}{c}\text { Variance } \\
\text { Decomposition of }\end{array}$ & Period & S.E. & RGDP & FDI & CAP \\
\hline & 1 & 24.84358 & 100.0000 & 0.000000 & 0.000000 \\
RGDP & 3 & 29.76159 & 78.56126 & 1.411433 & 20.02731 \\
& 10 & 48.1509361 .36338 & 19.77759 & 18.85903 \\
\hline & 1 & 2947.0246 .632009 & 93.36799 & 0.000000 \\
FDI & 3 & 4671.7175 .477845 & 93.53581 & 0.986345 \\
& 10 & 6878.225 & 4.067883 & 92.14956 & 3.782553 \\
\hline & 1 & 6896.020 & 12.18969 & 0.917332 & 86.89297 \\
CAP & 3 & 8517.677 & 14.39093 & 11.16268 & 74.44639 \\
& 10 & 13166.07 & 9.011344 & 50.81519 & 40.17346 \\
\hline
\end{tabular}

Table V presents for the Variance Decomposition results. This aims to examine the effects of shocks on the dependent variables. This technique determines how much of the forecast error variance for any variable in a system is explained by shocks to each explanatory variable in the short and long runs. The third period was used as a short run indicator and the tenth period is used as a long run indicator. The result shows a positive shock on RGDP, FDI and CAP in the short run (Quarter 3). The chock in RGDP causes about $78.56 \%$ of the fluctuation in RGDP (own chock). In addition, the chock in FDI causes about $1.41 \%$ of the fluctuation in RGDP and the chock in CAP causes about $20 \%$ of the fluctuation in RGDP. However, in the long run (Quarter 10) this effect will change and the chock in RGDP contributes for about $61.36 \%$ of the fluctuation in RGDP (own chock). While, the chock in FDI contributes for about $19.8 \%$ of the fluctuation in RGDP and the chock in CAP contributes for about $18.9 \%$ of the fluctuation in RGDP. 
And the chock in RGDP causes $5.5 \%$ of the fluctuation in FDI. While, the chock in FDI causes $93.59 \%$ of the fluctuation in FDI (own chock) and the chock in CAP causes about $1 \%$ of the fluctuation in FDI. But, in the long run these effects will change and the chock in RGDP contributes for about $4 \%$ of the fluctuation in FDI. Further, the chock in FDI can contribute for about $92 \%$ of the fluctuation in FDI (own chock) and the chock in CAP can contribute for $3.78 \%$ of the fluctuation in FDI.

From Table V, it can be noted that RGDP chock effect on RGDP, FDI and Cap in the long run is decreased. And the FDI chock effect on RGDP, FDI and Cap in the long run is increased. Also, the Cap chock effect on RGDP and FDI is increased but on Cap (own chock) is decreased in the long run.

Impulse response function (IRF) refers to the reaction of any dynamic system in response to some internal or external change. This can be used to produce the time path of the dependent variables in VAR to shocks from all the explanatory variables. In our VAR model, we have three variables. We can predict the response between these variables as plotted in Fig. 1.
Thus, from the IRF, we can note that the future responses of (EG) represented by RGDP \& FDI to Impulse in stock market represented by CAP and vice versa.

From Fig. 1, Graph (1) shows the IRF of RGDP to RGDP declines to be negative in the third period then it increases to positively fluctuate starting from the fourth period. Graph (2) shows the IRF of RGDP to FDI positively increases all the time. Graph (3) shows the IRF of RGDP to Cap negatively fluctuate all the time. Graph (4) shows the IRF of FDI to RGDP declines to hit zero at the tenth period. Graph (5) shows the IRF of FDI to FDI declines but not hitting zero at the long run. Graph (6) shows the IRF of FDI to Cap negatively fluctuates but around zero. Graph (7) shows the IRF of CAP to RGDP declines to reach zero at the second period then positively fluctuate from the fourth period but near to zero line. Graph (8) shows the IRF of CAP to FDI declines to be negative in the second period then it positively increases. Graph (9) shows the IRF of CAP to CAP declines to reach zero at the third period and negatively fluctuates. Noteworthy, if the system of equations is stable any shock should decline to zero or, an unstable system would produce an irregular path.
(1) Response of RGDP to RGDP

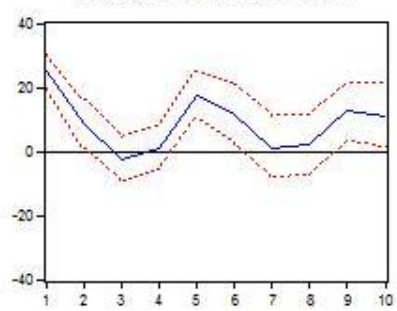

(4) Response of FDI to RGDP

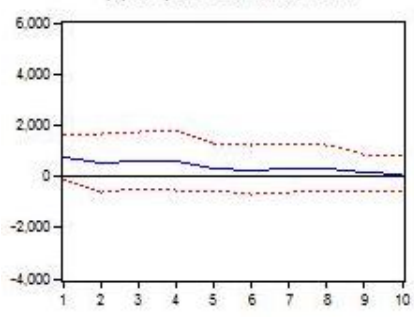

(7) Response of CAP to RGDP

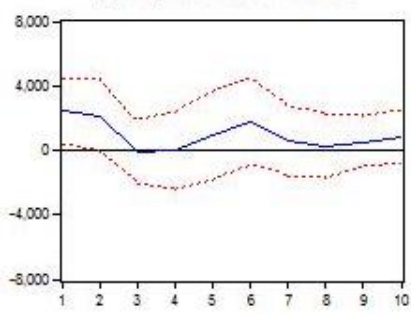

(2) Response of RGDP to FDI

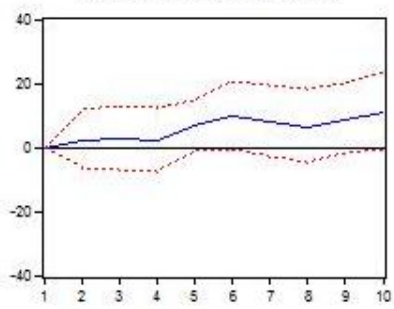

(5) Response of FDI to FDI

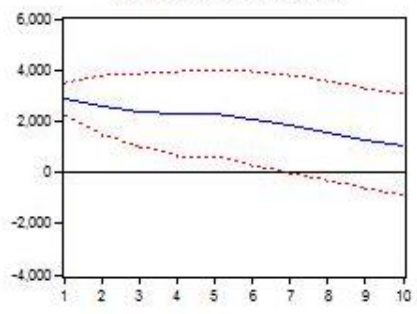

(8) Response of CAP to FDI

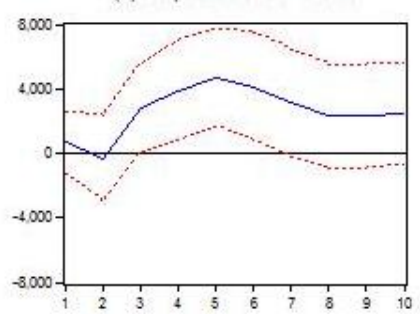

(3) Response of RGDP to CAP

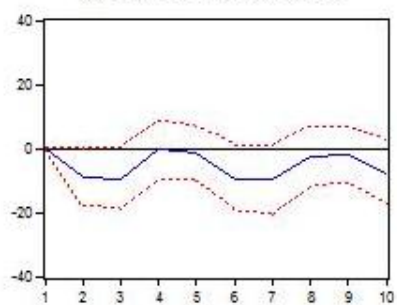

(6) Response of FDI to CAP

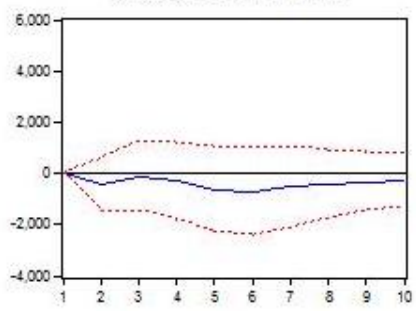

(9) Response of CAP to CAP

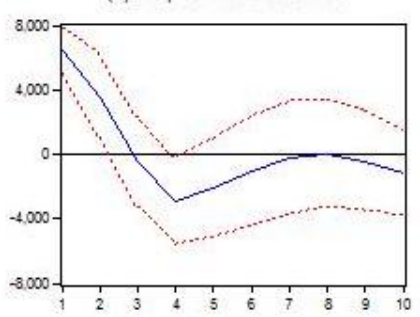

\pm 2 S.E.

\section{CONCLUSION}

The increasing importance of stock market has attracted researchers to study the impact of stock market development on economic growth. Although there are many similar researches, they do not examine the Egyptian economy. This study empirically investigates and tries to answer the question: Is there a causal relationship between the stock market development and the economic growth of the Egyptian economy? This study covers the period of 2002 Q1 to 2013 Q4 and uses the Real GDP and FDI as proxies for economic growth, and stock market capitalization as proxies for stock market development. It uses the Real GDP as internal proxies and FDI as external proxies.

Time series models are used to examine the unit root, cointegration and vector autoregressions among the variables in the short and long run and detect their dynamic causal interactions.

The results indicate that there is no a cointegration relationship between indicators of both stock market and economic growth in the long run. Using VAR analysis and causality test do not indicate a causal relationship between 
stock market development alone and the economic growth, but shows a link between stock market development in addition to foreign direct investment and economic growth. Therefore, the Egyptian stock market may be viewed as a casino that is not contributing to the economic growth of the country during the study period. Thus, the study deduces that the Egyptian stock market is weak, inefficient and does not contribute to the economic growth process, as it is based on speculation not on investment. Thus, the government should reshape and adjust the stock market to support economic growth. Finally, additional future research is needed to identify and prescribe the policy needed that induces a strong relationship between stock market development and the economic growth.

\section{REFERENCE}

[1] R. K. Filer, J. Hanousek, and N. F. Campos, "Do stock markets promote economic growth?" CERGE-EI Working Paper Series, p. $151,2000$.

[2] T. Beck and R. Levine, "Stock markets, banks, and growth: Panel evidence," Journal of Banking \& Finance, vol. 28, no. 3, pp. 423-442, 2004.

[3] C. K. Choong, Z. Yusop, S. H. Law, and V. K. S. Liew, "Financial development and economic growth in Malaysia: The perspective of stock market," Investment Management and Financial Innovations, vol. 2, no. 4, pp. 105-115, 2005.

[4] Bahadur, "Stock market and economic development: a causality test," The Journal of Nepalese Business Studies, vol. 3, no. 1, 2006.

[5] J. B. Ang and W. J. McKibbin, "Financial liberalization, financial sector development and growth: Evidence from Malaysia," Journal of Development Economics, vol. 84, no. 1, pp. 215-233, 2007.

[6] X. Liu and P. Sinclair, "Does the linkage between stock market performance and economic growth vary across Greater China?' Applied Economics Letters, vol. 15, no. 7, pp. 505-508, 2008.

[7] A. Vazakidis and A. Adamopoulos, "Financial development and economic growth an empirical analysis for Greece," American Journal of Applied Sciences, vol. 6, no. 7, p. 1410, 2009.

[8] S. Karacaer and A. Kapusuzoglu, "Investigating causal relations among stock market and macroeconomic variables: Evidence from Turkey," International Journal of Economic Perspectives, vol. 4, no. 3, pp. 501-507, 2010.

[9] L. M. Marques, J. A. Fuinhas, and A. C. Marques, "Does the stock market cause economic growth? Portuguese evidence of economic regime change," Economic Modelling, vol. 32, pp. 316-324, 2013.

[10] L. Cavenaile, C. Gengenbach, and F. Palm, "Stock markets, banks and long run economic growth: a panel cointegration-based analysis," De Economist, vol. 162, no. 1, pp. 19-40, 2014.

[11] A. A. Rad and F. Etemadmoghaddamb, "The effects of stock market and banking sector developments on economic growth in Iran: Evidence from Univariate framework analysis," 2014.
[12] X.-Q. Zhao, "Stock prices, inflation and output: Evidence from China," Applied Economics Letters, vol. 6, pp. 509-511, 1999.

[13] S. B. Naceur and S. Ghazouani, "Stock markets, banks, and economic growth: Empirical evidence from the MENA region," Research in International Business and Finance, vol. 21, no. 2, pp. 297-315, 2007.

[14] T. Azarmi, D. Lazar, and J. Jeyapaul, "Is the indian stock market a casino?" Journal of Business \& Economics Research (JBER), vol. 3, no. 4, 2011.

[15] L. Carp, "Can stock market development boost economic growth? Empirical evidence from emerging markets in central and eastern Europe," Procedia Economics and Finance, vol. 3, pp. 438-444, 2012.

[16] F. Rioja and N. Valev, "Stock markets, banks and the sources of economic growth in low and high-income countries," Journal of Economics and Finance, pp. 1-19, 2014.

[17] J. Guo, "Causal relationship between stock returns and real economic growth in the pre-and post-crisis period: Evidence from China," Applied Economics, pp. 1-20, 2014.

[18] S. Johansen, "Statistical analysis of cointegrating vectors," Journal of Economic Dynamics and Control, vol. 12, pp. 231-254, 1988.

[19] T. Afza and M. S. Nazir, "Economic competitiveness and human resource development: An FDI perspective," Pakistan Economic and Social Review, pp. 167-180, 2007.

[20] M. H. Ibrahim, "Stock market development and macroeconomic performance in Thailand," Engineering Economics, vol. 22, no. 3, pp. 230-240, 2011.

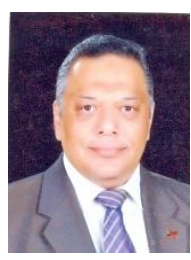

Osama M. Badr was born in Egypt in 1964. He received his B.Sc. degree in economics from Tanta University in 1986 and his M.Sc. degree in applied economy from Tanta University in 1998. He earned his Ph.D. degree in economics from the same university in 2007. He received his diploma of financial analyst for stocks, bonds and other investments from Concordia University, Canada in 1997.

$\mathrm{He}$ is now serving as an assistant professor of economics (visitor) in College of Management at Umm Al-Qura University, KSA where he joined in 2011. He works as an economics lecturer in Tanta University since 2006, $\mathrm{He}$ worked as an economics assistant lecturer from 1999 to 2006, a financial analyst from 1993 to 1997, a credit supervisor in Bank of Credit and Commerce from 1987 to 1993. He teaches principles of economics, macroeconomics, public finance, fiscal policy, money and banking, international economy and foreign trade and modern economic problems by relating theories to his six-year experience in banking industry and ten years in financial analyses. His research interest focuses on economic policies and economic growth of developing economies. He has published one English book on fiscal policy and five Arabic books on public finance, fiscal policy, money and banking, foreign trade and modern economic problems. 